\title{
Personalized Medicine pada Pelayanan Kesehatan Reproduksi
}

\author{
Djamhoer Martaadisoebrata \\ Departemen Obstetri dan Ginekologi Fakultas Kedokteran Universitas Padjadjaran Rumah \\ Sakit Dr. Hasan Sadikin Bandung \\ Korespondensi: dmas1931@ymail.com
}

\begin{abstract}
Abstrak
Tujuan: Untuk mencoba mencari kejelasan kelemahan dan keunggulan berbagai paradigma dan mencoba membuktikan bahwa Personalized Medicine itu adalah paradigma yang terbaik, sampai saat ini.

Metode: Studi Pustaka

Hasil: Dengan seiring waktu Clinical Medicine juga mendapatkan tambahan pengembangan dari Evidence Based Medicine dan Genome Medicine. Personalized Medicine lebih mengembangkan ilmu kedokteran sesuai dengan individu masing-masing sehingga menjadi lebih baik.

Kesimpulan: Walaupun terbukti bahwa Clinical Medicine, Evidence Based Medicine dan Genome Medicine mempunyai kelemahan di samping keunggulannya masing-masing, tetapi ketiga paradigma tersebut masih bisa digunakan, pada kondisi dan dan situasi tertentu. Personalized Medicine, sampai saat ini, masih yang terbaik, karena dalam pelaksanaannya terungkap sifat yang Holistik, Humanistik dan penuh Empati. Dengan perkataan

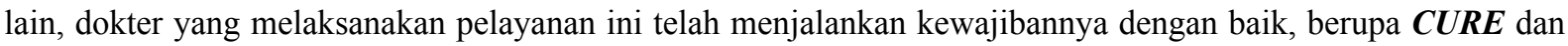
$\boldsymbol{C A R E}$ secara proporsional, suatu sifat yang bisa membuktikan keprofesionalannya.
\end{abstract}

Kata kunci: Personalized medicine, pelayanan kesehatan dan kesehatan reproduksi.

\section{Personalized Medicine in Reproductive Health Service}

\begin{abstract}
s
Objectives: To look for any weakness and superiority for each of those paradigms and try to prove that Personalized Medicine is the best method in health service, until today.

Method: Literature review

Result: Developing clinical medicine also followed by Evidence Based Medicine and Genome Medicine other wise personalize medicine developing medical practice individuality to be better.

Conclusion: Although we know Clinical Medicine, Evidence Based Medicine and Genome Medicine have some weaknesses, we also believe that those paradigms still can be used in certain conditions and situations. Mean while Personalized Medicine, until present time, is still the best method, because during its implementation, it describes its characteristic of Holistic, Humanism and full of Empathy. In other words, a physician who acts this way, is performing his obligation in the form of CURE and CARE, proportionally, an effort that can be considered as a sign of his professionalism.
\end{abstract}

Key word: Personalized Medicine, health service and reproductive health. 


\section{Pendahuluan}

Semua petugas kesehatan, khususnya dokter Spesialis Obstetri \& Ginekologi (SpOG), dalam memberikan pelayanan kepada pasien harus bertindak profesional. Ciri-ciri dokter yang profesional itu adalah:

1. Menguasai Ilmu dan Bioteknologi yang mutakhir

2. Menguasai keterampilan yang sesuai dengan Standar Profesi.

3. Mempunyai Niat, Sikap dan Perilaku yang Etis.

4. Mempunyai jiwa kepemimpinan.

Tiap kali seorang dokter menangani pasien, tujuannya tidak lain dari menghilangkan penyakit atau paling tidak mengurangi keluhannya. Di samping itu, harus pula diperhatikan kepuasan, kenyamanan, harapan dan rasa optimisme dari pasien. Agar tujuannya bisa tercapai, dokter tersebut harus membuat diagnosis dan menyarankan berbagai intervensi yang tepat. Kedua keputusan ini disebut sebagai Clinical Decision atau Keputusan Klinik.

Keputusan Klinik ini, harus merupakan hasil analisis yang matang, gabungan dari kemampuan intelek akademis profesional dalam mencari dan menilai data, serta kemampuan untuk mengkomunikasikan data tersebut kepada pasien/keluarga secara baik. Pola pikir atau paradigma ini telah dikenal sejak zaman Hippocrates dan disebut sebagai Clinical Medicine $\boldsymbol{e}^{1}$ atau Kedokteran Klinik. Sesuai dengan dengan perkembangan ilmu dan bioteknologi, paradigma ini terus berkembang sampai sekarang dan dikenal sebagai Kedokteran Modern.

Pada dasarnya, semua ilmu, agar bisa bermanfaat, harus terdiri dari tiga bagan besar yaitu Wawasan, Kebijakan dan Kompetensi. ${ }^{2}$ Dalam wawasan, kita bicara tentang pengertian, tujuan, ruang lingkup dan garapannya. Dalam perkataan lain, wawasan bicara tentang keilmuan, misalnya ilmu kedokteran itu apa.

Agar ilmu itu bisa bermanfaat, terutama untuk manusia, harus diwujudkan dalam bentuk keterampilan yang disebut Kompetensi. Contohnya agar seorang dokter atau bidan bisa memanfaatkan ilmu kebidanan, mereka harus mempunyai keterampilan untuk memeriksa ibu hamil, menolong ibu bersalin dan merawat ibu dan anak pada masa nifas dengan baik.

Namun wawasan dan kompetensi saja tidak cukup, karena masih diperlukan arahan dan rambu-rambu berupa suatu Kebijakan atau Program, agar penggunaan ilmu dan keterampilan benar-benar berguna bagi pasien dengan efek samping yang seminimal mungkin.

Dalam dunia Clinical Medicine, yang disebut Kebijakan itu dibuat oleh para klinisi dengan istilah Protokol Tetap Pengelolaan Penyakit. Di kalangan mahasiswa kedokteran dan calon spesialis istilah ini lebih dikenal dengan nama Protokol Tetap atau Protap. Dalam Protap tersebut sudah tercantum cara membuat diagnosis, penawaran berbagai alternatif terapi, yang pada gilirannya, agar memberikan berbagai prognosis.

Para calon spesialis, pada saat mempresentasikan dan membahas suatu kasus, demi untuk mempertahankan argumentasinya bahwa mereka telah bertindak benar sering mengatakan bahwa pasien ini telah dikelola sesuai dengan Protap yang berlaku tetapi hasilnya tidak sesuai dengan yang diinginkan, bahkan ada yang meninggal. Mengapa? Mengapa Protap yang sudah disepakati itu tidak selalu bisa menjamin keberhasilan pengobatan?

Karena waktu kita diharuskan untuk mempelajari ilmu dan menguasai Protap, kita bicara dalam pengertian PENYAKIT, sesuatu yang tidak berjiwa dan tidak berperasaan. Sedangkan pada saat kita melayani pasien yang kita hadapi adalah MANUSIA YANG SAKIT yang berjiwa, berperasaan dan berkemauan. Di samping mempunyai penyakit, pasien itu mempunyai 
masalah lain seperti sosekbud yang berpengaruh terhadap penampilan dan perjalanan penyakit serta hasil pengobatan. Selain dari pada itu, Protap yang kita sepakati dibuat berdasarkan ilmu dan keterampilan yang kita kuasai saat itu, padahal kita ketahui bahwa ilmu dan bioteknologi itu selalu berkembang. Dengan demikian, Protap yang kita pakai tidak pernah sempurna dan bersifat NISBI.

Seorang dokter yang menggunakan ilmu dan keterampilannya untuk menangani penyakit tertentu, tanpa memperhatikan manusianya, kurang menunjukkan sifat profesionalismenya. Seperti yang dikatakan oleh Martin Sass, ${ }^{3}$ penyakit itu terjadi oleh karena ada gangguan dalam keseimbangan. Tugas dokter adalah untuk mengembalikan keseimbangan tersebut, memerangi disharmoni dan ketidak seimbangan tersebut dan menerima dan serta menyadari keterbatasan kemampuan (Ekspertis) kedokteran sebagai keterbatasan alamiah dalam memanipulasi manusia. Menurut pendapatnya, praktek kedokteran, dari dahulu sampai sekarang, selalu dipandu oleh prinsip-prinsip Etika. Dua di antaranya adalah nil nocere(do not harm) dan bonum facere (do good for the patient). Secara tradisi, Ekspertis dan Etika selalu merupakan kesatuan, sebab :

\section{Ekspertis tanpa Etika, tidak akan membahagiakan pasien, sedangkan Etika tanpa Ekspertis, tidak akan efektif dan harus disadari bahwa Ekspertis kita itu mempunyai keterbatasan.}

Yang dimaksud dengan Ekspertis itu tidak lain dari penguasaan Protap yang digunakan dalam Clinical Medicine. Atau dengan istilah lain, disebut $\boldsymbol{C} \boldsymbol{U} \boldsymbol{E}$, yaitu upaya yang ditujukan kepada PENYAKTNYA, sedang upaya yang ditujukan kepada ORANG SAKIT-nya, disebut Etika atau $\boldsymbol{C A R E}$.

\section{Jadi pelayanan kesehatan yang paripurna adalah gabungan dari CURE dan CARE yang proporsional.}

Dengan uraian tersebut di atas, dapat kita simpulkan bahwa dalam Clinical Medicine WAWASAN-nya bertujuan untuk memberi pelayanan kesehatan yang terbaik kepada pasien, baik dilihat dari fisik, mental maupun sosial. KEBIJAKAN-nya, berupa arahan atau ramburambu, sehingga tujuan pelayanan tersebut bisa tercapai, yang dalam kesehari-hariannya disebut PROTAP, sedangkan KOMPETENSI-nya berupa Skill atau keterampilan klinik yang harus dikuasainya sesuai dengan Standar Profesi yang berlaku. Oleh karena itu, sesuai dengan pengertian profesional, kita para dokter, harus mau belajar seumur hidup, demi untuk menjaga citra profesi kita. Seorang dokter yang profesional, harus selalu berpegang kepada slogan yang berbunyi

\section{Once a Professional, always a Student.}

Dalam melayani pasien, dokter membuat diagnosis, lalu menawarkan berbagai alternatif intervensi. Tujuan intervensi itu tidak selalu, tergantung kepada keadaan dan kebutuhan pasien, bisa berupa:

1. Promosi dan Prevensi.

2. Mengurangi sakit atau penderitaan.

3. Mengobati penyakit.

4. Dan lain-lain. 
Ada kalanya tujuan intervensi tidak selalu jelas, karena diagnosis dan kondisi pasien yang meragukan, sehingga William Osler mengatakan:

\section{Clinical Medicine is a science of uncertainty and the art of probability.}

Tugas dokter adalah untuk mengurangi ketidakpastian itu, melalui pengumpulan data, pengetahuan kedokteran dan daya nalar klinis untuk membuat diagnosis dan rencana terapi yang dibutuhkan pasien. Proses pengurangan ketidakpastian itu dan upaya yang konsisten untuk membuat keputusan yang baik disebut Clinical Judgement. Digabung dengan sikap empati, pengakuan hak otonomi pasien, komunikasi yang baik dan beneficence, Clinical Judgement itu disebut dan merupakan "The Art of Medicine". Art atau Seni itu dianggap sebagai suatu "proses intuitif” yang sulit dianalisa. Karena itu mereka mengatakan bahwa :

\section{Evidence Based Medicine aims at the reduction of uncertainty.}

Kalau kita bandingkan dengan uraian di atas, agaknya Clinical Judgement itu tidak berbeda dengan Kebijaksanaan yang diambil berdasarkan Kebijakan atau Protap, dan bahwa Art itu, walaupun tidak berdasarkan nalar, memang mempunyai peranan penting dalam dunia Medicine. Harus disadari, kebijaksanaan klinik itu akan meningkat sesuai dengan pengalaman, sedangkan kebijakan klinik akan terus menurun, bila para dokter tidak mau belajar lagi.

Dalam kaitan dengan $E B M$, ada beberapa pertanyaan yang harus kita jawab, yaitu :

1. Apa itu $E B M$ ?

2. Apa hubungannya dengan Clinical Medicine?

3. Apa benar bahwa EBM bisa mengurangi ketidakpastian Clinical Medicine?

4. Apakah EBM itu merupakan paradigma lanjutan dari Clinical Medicine?

5. Apakah Art atau "Intuisi" itu, mempunyai tempat dalam $E B M$ ?

Di dalam ensiklopedia Wikipedia, tercantum, bahwa menurut sejarahnya, pola pikir EBM itu sudah dikenal sejak zaman Yunani kuno.

Archie Cochrane (1972), ${ }^{4}$ seorang epidemiologist, melalui bukunya Effectiveness and Efficiency: Random Reflection on Health Service, menambah kepopuleran tentang konsep EBM.

Secara eksplisit, metodologi yang digunakan untuk menentukam "the best evidence", sebagian besar diperkenalkan oleh McMaster University, di bawah pimpinan David Sackett dan Gordon Guyatt.. Kemudian Guyatt, pada tahun 1990, mengumumkan kata "evidence based", dan baru tahun 1992, istilah "evidence based medicine" muncul dalam kepustakaan kedokteran.

Pada perkembangannnya, EBM mengalami pasang surut, dalam arti kata, ada yang setuju dan ada pula yang menolaknya. Pada dasarnya, dalam pelaksanaannya, EBM merupakan integrasi antara "individual clinical expertise" dengan "best available external evidence".

Pada tahun 1996, Sackett $\mathrm{D}^{5}$ dkk mengatakan bahwa EBM, secara falsafahi, mulai berkembang, sejak abad ke sembilan belas, dan tetap merupakan paradigma yang penting bagi para klinisi, akhli kesehatan masyarakat, purchasers, planner dan masyarakat umum. Sackett mengatakan bahwa $E B M$ itu adalah: 
Evidence Based Medicine is the conscientious, explicit and judicious use of current evidence in making decisions abaut the care of individual patients.

Kemudian disempurnakan menjadi:

The practice of EBM means integrating individual clinical expertise with the best available external research clinical evidence from systematic research and patient values.

Sedang Clinical Expertise adalah:

The ability to use our clinical skills and past experiense to rapidly identify each patient's unique health state and diagnosis, their individual risk and potential intervention, and their personal values and expectations.

Bukti dari peningkatan expertise-nya dapat dilihat, antara lain, dari cara membuat diagnosis dan terapi yang lebih efektif, efisien dan aman, serta sikap dan perhatiannya terhadap kesulitan, hak dan apa yang diinginkan oleh pasien. Hal ini tidak banyak berbeda dengan Ekspertis seperti dimaksud oleh Martin Sass atau Protap yang digunakan dalam Clinical Medicine. Ini berarti ada hubungan antara EBM dan Clinical Medicine.

Sedangkan Clincal Research itu adalah:

Clinical relevant research, often from the basic medicine, but especially from the patientcentered clinical research, on accuracy of diagnosis, efficacy and safety theraphy, rehabilitation and prevention regimens, and the power in prognostic marker.

Yang dianggap bukti terbaik (External Best Evidence) adalah :

1. Randomised Clinical Trial (RCT)

2. Systemic reviews of study

3. Large case report

4. Expert opinion

5. Personal experience

Berdasarkan uraian di atas, external evidence mempunyai hierarki, yang terbaik berasal dari $R C T$, sedangkan pengalaman pribadi, mempunyai nilai yang paling rendah. Konsekuensinya, kalau kita sudah mempunyai bukti baru berdasarkan penelitian klinik, maka Diagnosis dan Terapi yang lama sudah tidak berlaku lagi, dan diganti dengan yang baru. Betulkah??? Kalau memang benar, apakah ini berarti bahwa EBM dapat mengurangi ketidakpastian Clinical Medicine dan juga merupakan lanjutan dari padanya?

Seperti diterangkan di atas, EBM itu adalah integrasi dari Clinical Expertice, Best Research Evidence dan Personal Values. Apa dimaksudkan dengan Personal Values itu?

Menurut Sackett D dkk, Personal Values adalah:

The preference, concerns and expectation each patient brings to a clinical encounter and which must be integrated into clinical decisions, if they are to serve the patiens. 
Dengan pengintegrasian ketiga elemen ini, dokter dan pasien membuat kesepakatan dalam membuat diagnosis dan terapi, yang pada gilirannya, akan berpengaruh terhadap hasil pengobatan dan Quality of Live ( $Q O L)$.

Kalau kita bicara tentang personal values dan $Q O L$, berarti yang dipikirkan bukan hanya Penyakit-nya saja, yang mempunyai nilai Nalar Murni, tetapi para dokter itu memikirkan juga tentang Manusia-nya yang Sakit, yang mempunyai nuansa Rasa yang bersifat Intuitif dan berdasarkan Nurani (Art). Dengan demikian berarti bahwa Art itu mempunyai tempat dalam EBM.

External clinical evidence selalu berubah sesuai dengan perkembangan ilmu dan bioteknologi. Tetapi external clinical evidence hanya mempunyai nilai informatif, dan tidak akan bisa menggantikan individual clinical expertise. Justru expertise inilah yang menentukan apakah external evidence itu dapat digunakan pada individual patient (pasien tertentu) dan bagaimana cara mengintegrasikannya ke dalam clinical decison.

Para klinisi itu sadar, bahwa dalam menangani pasien, mereka selalu memerlukan informasi tambahan, antara lain karena tiap pasien mempunyai karakteristik masing-masing. Sedangkan mereka, pada umumnya, tidak mempunyai waktu untuk melakukan penelitian. Karena itu, untuk mendapat informasi tambahan, mereka harus mengikuti kegiatan ilmiah atau pelatihan secara teratur atau membaca jurnal kedokteran yang mutakhir. Karena EBM itu merupakan hasil nalar murni, maka perannya adalah untuk menawarkan Protokol atau Kebijakan Baru terhadap suatu penyakit, yang pada gilirannya, dapat membuat Clinical Decision yang baik. Dalam keseharihariannya, EBM itu disebut Evidence Based Practice (EBP) yang dalam pelaksanaannya, dianjurkan untuk membuat langkah-langkah yang terarah dan sistematis, yaitu:

\section{Lankah I: Define a Clinical Question}

Ajukan pertanyaan kepada pasien, untuk memformulasikan masalah penyakit, apakah itu masalah prevensi, diagnosis, terapi atau prognosis.

\section{Langkah II: Find the best Evidence}

Cari Evidence Terbaik di kepustakaan mutakhir, yang dapat digunakan untuk menjawab pertanyaan yang tercantum pada Langkah I.

Langkah III: Asses the Evidence

Lakukan "critical appraisal" terhadap Evidence tersebut, apa dapat digunakan.

Langkah IV: Intergrating the Evidence with our clinical expertice and patient's factors

Gunakan Evidence itu pada pasien.

\section{Langkah V: Evaluating the result}

Bicarakan semua in dengan pasien dan evaluasi hasilnya.

Jenicek $\mathrm{M}^{6}$ mempermasalahkan kaitan antara Epidemiologi dan Public Health dengan $E B M$. Menurut pendapatnya, banyak prinsip, metoda dan teknik Epidemiologi yang dapat digunakan dalam EBM sehingga Evidence Based Practice Public Health dapat dipikirkan perkembangannya, walaupun terbatas. Dhavendra Kumar, ${ }^{7}$ dalam artikelnya: "From evidence based medicine to genomic medicine," menceritakan bahwa sejak Hippocrates sampai 
Kedokteran Modern, setiap calon dokter diajari untuk membuat anamnesis tentang keluhan pasien dan riwayat penyakitnya, kemudian memeriksa gejala dan gambaran kliniknya. Bukti individu ini kemudian disatukan dengan data eksternal yang berasal dari laboratorium dan pencitraan. Jadi menurut Kumar, pada dasarnya EBM itu adalah "Personalized Medicine", satu bentuk dari "good medical practice" yang dapat diterima. Keberhasilan EBP tergantung kepada kekuatan translational reseach, tetapi aplikasi hasil penelitian ke dalam praktek klink, sangat lambat dan sukar.

Walaupun $E B P$, pada umumnya dapat diterima oleh klinisi, petugas, perencana dan manajer kesehatan, tetapi hal ini belum sepenuhnya merupakan bagian dari profesi medik maupun kesehatan, antara lain, karena para klinisi sering mendapat kesukaran dalam memilih bukti yang terbaik.

Yang menarik dalam artikel ini adalah perkembangan EBM ke arah Genetics/Genomics Medicine dan Personalized atau Individualised Medicine. Manusia itu terdiri dari sistem organ, jaringan, sel dan komponen sel, yaitu profil genetik dan genomik. Hasil penelitian dasar tentang gen dan genom, yang disebut penelitian Biomolekuler, mungkin akan dan bisa digunakan dalam EBM sebagai external evidence yang baru.

Pengetahuan yang didapat dari pendekatan individu, sekarang sudah berhasil diaplikasikan dalam kesehatan masyarakat dan populasi, dalam bentuk vaksin, pengawasan infeksi dan gizi. Di samping itu, digunakan pula dalam pengawasan penyakit menular (communicable diseases), dan dalam keadaan tertentu, digunakan pula dalam pengawasan penyakit tidak menular (non communicable diseases), seperti obesitas, diabetes melitus, penyakit jantung, kanker dll. Praktek kedokteran modern sekarang terdiri dari promosi kesehatan, pencegahan dan pengobatan penyakit, dan sedang dalam transformasi dari EBM ke dalam Genomic Medicine. Apakah dengan munculnya Genomic Medicine, berarti paradigma EBM hilang? Atau EBM tetap ada, tetapi dalam proses penggunaannya dipakai Evidence yang berasal dari penelitian dasar, termasuk penelitian gen dan genom?

Personalized Medicine, saat ini, banyak diperbincangkan di kalangan ahli kesehatan. Kumar mengatakan bahwa :

\section{Whatever maybe the argument, in favor or against personalized or individualised medicine care, this is what is expected by the patient and this is what every clinician is professed to deliver.}

Menurut Rajkumar T, ${ }^{\mathrm{x}}$ saat sekarang, pelayanan yang diberikan kepada pasien, dengan penyakit tertentu, diberikan berdasarkan data yang didapat dari ribuan pasien. ternyata anggapan ini tidak selalu benar. Ada kasus-kasus di mana pengobatan menimbulkan efek samping yang berat, bahkan fatal. Hubungan efek samping dan dosis obat yang digunakan, tidak selalu dapat diprediksi.

Revolusi dalam bidang Genom, memungkinkan diberikannya obat yang paling tepat untuk orang-orang tertentu, bukan saja dalam efektivitasnya, tetapi juga cara menghidarkan efek samping. Jadi, saat sekarang, pelayanan medik disesuaikan dengan karakeristik masing-masing, berdasarkan informasi Genom. Dengan demikian, bentuk pelayanannya dapat disebut sebagai Personalized Medicine.

Pada kesimpulannya, artikel ini mencoba menarik perhatian para pakar temtang pentingnya EBM, suatu konsep yang mapan dalam praktek Clinical Medicine Modern. Para klinisi di masa 
yang akan datang, harus dilengkapi dengan ilmu dan keterampilan membuat diagnosis dan terapi, berbasis Genom.

Berdasarkan uraian di atas, kita melihat ada kesinambungan antara Clinical Medicine, EBM, Genomic Medicine dan Personalized Medicine. Walaupun EBM itu sangat dianjurkan, banyak pakar kesehatan yang mengatakan bahwa EBM itu bukan segala-galanya. Bahwa EBM itu mempunyai kelemahan, antara lain dikatakan, bahwa research evidence merupakan hasil Nalar Murni, tanpa memperhatikan Rasa dan Intuisi, sehingga kalau tidak hati-hati, EBM itu bisa "Tidak Berperasaan", padahal akan digunakan pada manusia yang berperasaan dan berkemauan.

Jonsen dkk, ${ }^{9}$ dalam bukunya mengatakan bahwa ada pasien yang masuk dalam keadaan "moribound" atau "about to die". Dalam keadaan semacam ini, semua fungsi organ menurun secara drastis dan irreversible. Kematian diperkirakan akan terjadi dalam beberapa jam. Apa pula pasien yang dirawat dengan diagnosis "stadium terminal", yang berarti intervensi apapun yang diberikan, pasien ini akan meninggal juga dalam waktu yang tidak terlalu lama, maksimal sampai enam bulan. Dalam kedua kasus di atas, clinical judgement, tidak mudah dilakukan, termasuk penggunaan $E B M$.

Andrew Miles, Loughlin $\mathrm{M}$ and Polychronis $\mathrm{A}^{10}$ pada taun 2008, menulis artikel dengan judul "Evidence Based health care, clinical knowledge and the rise of personalized medicine", dan mengambil kesimpulan bahwa secara umum, para penulis, tidak sepakat dengan paradigma $E B M$, baik dilihat dari segi falsafah, konsep, maupun implementasinya, dan mengatakan bahwa:

The essence of clinical practice is the provision of personal medicine service through the mechanism of consultation. The place of EBM, and science more broadly, is utterly subordinate to this. The advent of patient centredness and shared clinical decision making and the rise in importance genomic and translational sciences is rapidly marginalising

EBM, so that the concept of EBM is losing influence as the promises and potential personalized medicine are increasingly recognized.

EBM is initially known as a "clinical epidemiology", the application of epidemiological data to clinical practice. That is what is was, what is always has been and that is what it remains.

Sedangkan dalam makalah lain, Andrew Miles dan JuanMezzich, ${ }^{11}$ dalam artikelnya yang berjudul: The care of the patient and soul of clinic: personalized medicine as an emergent model of modern clinical medicine, mengatakan:

As medicine has become more powerfully scientific, it has also become depersonalized, so that in areas of clinical practice an over-reliance on science in the care of patients has led to the substitution of scientific medicine with scientistic medicine and accompanying collapse of human values in the profession of medicine. Since medicine has the unalterable imperative to care, comfort and console as well as to ameliorate, attenuate and cure, the prepertuation of modern myth in medicine-that now we cure we have no more responsibility to care-risk the creation of ethical and moral chaos within clinical practice and the generation of negative outcome for to patient and clinicians alike.

We recommended that such a development should take place as a part of a wider shift within health service, assisting a move away from impersonal, fragmented and 
decontextualized systems of health care toward personalized, integrated and contextualized of clinical practice, so that affordable biomedical and technological advance can be delivered to patients within humanistic framework of care which recognizes the importance of applying science in a manner which respects the patients as a person and takes full account of his values, preferences, stories, cultural contex, fears, worried and hope and thus recognizes and responds to physical need. This, we contend, is personalized medicine, an emergent model of modern clinical practice.

Agaknya, menurut artkel ini, tujuan utama dari pelayanan kesehatan itu adalah untuk menyembuhkan PENYAKIT (how to CURE the Disease) saja, tanpa memperhatikan kepuasan dan kenyamanan ORANG SAKIT-nya (how to CARE the Patient). Padahal sesungguhnya, yang kita inginkan adalah gabungan dari $\boldsymbol{C} \boldsymbol{U R E}$ dan $\boldsymbol{C A R E}$ secara proporsional.

Dengan penjelasan di atas, kedua penulis itu, ingin menggambarkan bahwa paradigma Personalized Medicine adalah pelayanan kesehatan yang paripurna, Holistik, Humanistik dan penuh Empati. Bukan saja penyakitnya yang menjadi perhatian, tetapi juga orang sakitnya. Dengan ilmu dan bioteknologi yang mutakhir, kita bisa memberikan CURE untuk menyembuhkan penyakitnya atau paling sedikit mengurangi penderitaaannya. Di samping itu, kita tidak boleh melupakan orang sakit-nya. Dengan penuh empati, kesabaran dan keikhlasan kita tangani para pasien, agar mereka merasa puas, nyaman dan penuh harapan. Itulah yang disebut CARE. Melalui CURE, kita sampaikan kemampuan klinik kita (Clinical Expertice). Dengan $C A R E$ kita tunjukan rasa Etika kita. Kalau kita sudah bisa memberi memberikan pelayanan yang mencakup $C U R E$ dan $C A R E$ secara proporsional, kita sudah bertindak secara profesional.

Pada saat ini, makin banyak para klinisi yang mempercayai dan mengikuti paradigma ini. Di antara mereka ada yang menyelenggarakan International Conference on Personalized Medicine di Silicon Valley pada tanggal 26 Januari 2015. ${ }^{12}$ Kemudian, di Valencia, Spanyol, dilaksanakan $3^{\text {rd }}$ International Conference on Preditive, Preventive and Personalize Medicine and Moleculer Diagnostics, ${ }^{13}$ pada tanggal 1-3 September 2015.

Mark Kris, ${ }^{14}$ dari Memorial Sloan-Kettering Oncology Service, mengatakan bahwa Personalized Medicine, telah digunakan dalam mengobati Non-Small Cell Lung Cancer.

Sedangkan menurut Redho Meisudi, ${ }^{15}$ dari Jakarta, saat ini, di Indonesia, paradigma ini sudah digunakan dalam mengobati lima jenis kanker, yaitu: Non-Small Cell Cancer, Metastatic Colorectal Cancer, Breast Cancer, Chronic Myeloid Leukemia and Head \& Neck Cancer.

Marilah kita simak arti dari Personalized Medicine ini. Hal ini tidak mudah, karena perkembangan paradigma ini bisa atau ada bermacam-macam. Pada waktu Sackett D mengatakan bahwa EBM itu adalah integrasi antara Clinical Expertise, Best External Evidence dan Personal Values, apakah ini tidak berarti bahwa clinical decision yang dibuat itu diarahkan kepada pasien tertentu? Kalau benar demikian, apakah ini bukan Personalized Medicine? Tetapi di sini external evidence-nya bukan berbasis genom atau genetik.

Dalam perkembangan selanjutnya, best external evidence yang semula berasal dari hasil penelitian klinik, kemudian ditambah dengan penelitian dasar atau biomolekuler tentang gen atau genom. Inilah yang disebut Genomic Medicine. Seperti yang dikatakan oleh Rajkumar, EBM itu adalah suatu konsep yang mapan dalam Clinical Medicine Modern. Para klinisi di masa yang akan datang harus dilengkapi dengan ilmu dan ketrampilan untuk membuat diagnosis dan terapi berbasis Genom. Karena pemeriksaan genetik itu dilakukan pada tingkat Sel, maka paradigma ini disebut Cellular Personalized Medicine atau Kedokteran Personal Seluler. 
Berdasarkan informasi dari internet(http://www.personalizedmedicine.com) ${ }^{16}$ Personalized Medicine ini adalah perkembangan lebih jauh dari cara yang tradisonal, hanya di sini cara pengobatannya lebih spesifik. Teknologi yang digunakan untuk membuat diagnoss dan $\mathrm{Th} /$ lebih canggih, antara lain, melalui Genetic Mapping. Genomic atau Personalized Medicine menggunakan informasi genetik untuk mencegah dan mengobati penyakit pada orang dewasa maupun anak-anak.

Menurut Wikipedia, ${ }^{17}$ pengertian Personalized Medicine itu adalah:

Personalized Medicine is a medical model emphasizing in general the customization of health care, with all decision and practices being tailored to individual patients in whatever ways possible.

Pada era pascagenome, teknologi lain mulai masuk ke dalam pemerikasaan klinik. Contohnya, pada masa yang akan datang, Proteomics, mungkin akan memberikan pengaruh yang besar pada Personalized Medicine, sebab walaupun DNA genome itu merupakan pusat infomasi, tetapi pada dasarnya, Protein-lah yang mengerjakan pekerjaan sel itu. Secara fungsional, sel itu dikontrol oleh Protein, bukan oleh Gene. Konsekuensinya, protein-based assay-lah yang diakui oleh Food and Drug Administration (FDA) untuk membuat diagnosis, melalui teknik "immunohistochemistry" atau IHC. Fungsi-fungsi biologis yang penting, seperti pertumbuhan, kematian, pergerakan dan lokalisasi sel dll, semua dikontrol oleh proses yang disebut Signal Transduction. Jadi para pakar, saat sekarang, menganggap bahwa analisa langsung dari proteomic lebih diperlukan dari pada analisa melalui genomic atau genetic.

Merujuk ke Harian Kompas ${ }^{(18)}$ tertanggal 18 Juni 2009, Personalized Medicine diartikan sebagai "Personalisasi Perawatan", artinya:

\section{Sistem pengobatan dengan mempelajari genotipe pasien sehingga pasien mendapat terapi atau obat yang paling tepat untuk penyakitnya.}

Dr Hera Noviana, ${ }^{19}$ seorang Molecul Biologist dari Kalbe Genomic Laboratory, pada 19 Mei 2011, menerangkan, bahwa pada pengobatan kanker secara konvensional, pasien akan datang kepada dokter, ditentukan diagnosisnya dan diberi terapi. Kalau gagal, obatnya akan diganti yang lain. Penggantiannya bisa terjadi beberapa kali, sehingga mengambil waktu yang lama dan menambah biaya.

Pada Personalized Medicine, pasien akan diperiksa secara klinik, kemudian dilakukan uji genetik. Dari hasilnya, berupa petanda kanker (biomarker), kita bisa menentukan pengobatan yang cocok untu masing-masing orang, sehingga respons terhadap obatnya pun baik, efektif, aman dan lebih murah.

Keuntungan lainnya adalah :

1. Deteksi dini pasien yang berisiko mengembangkan penyakit tertentu.

2. Mendapatkan pengobatan yang lebih tepat.

3. Mengurangi toksisitas, terutama bagi pasien yang tidak mendapat keuntungan dengan terapi tersebut.

4. "Smart" design studi klinik.

5. Memaksimalkan potensi obat. 
Pada tahun 2012, di Harian Kompas, dibuat artikel yang berjudul "Integrasi Ilmu Dasar Ilmu Klinik" yang ditulis oleh Prof David Handoyo Mulyono. ${ }^{20}$ Profesor tersebut mengatakan bahwa integrasi penelitian dasar dan kedokteran klinik akan membuka jalan untuk Personalized Medicine, yaitu menyesuaikan terapi dengan kondisi tubuh pasien terkait. Yang dimaksud dengan ilmu dasar, antara lain, pemahaman genotipe virus Hepatitis B terkait pengobatan dan mutasi virus dalam kaitannya dengan perkembangan penyakit sirosis dan kanker hati. Atau penelitian gen BRCA1 dan BRCA2 untuk diteksi dini kanker payu dara.

Menurut penulis, Personalized Medicine ini dapat digunakan untuk mengobati Gestational Trophoblastic Neoplasm (GTN), suatu bentuk yang ganas dari Gestational Trophoblastic Disease (GTD), GTD adalah sekelompok penyakit yang berkaitan dengan kehamilan yang terdiri dari Hydatidiform Mole (HM) yang jinak dan Gestational Trophoblastic Neoplasm $(\boldsymbol{G T N})$ yang ganas. HM terbagi lagi dalam Complete Hydatidiform Mole (CHM), Partial Hydatidiform Mole (PHM) dan Recurrent Hydatidiform Mole (RHM). GTN dibagi lagi dalam tiga jenis, yaitu Choriocarcinoma, Invasive Mole dan Placental Site Trophoblastic Tumor.

Sesuai dengan perkembangan ilmu dan bioteknologi, kita sekarang sudah mengetahui tentang sitogenetik, termasuk gambaran genetiknya. Diskripsi genetik pada $\boldsymbol{C H} \boldsymbol{M}$ adalah Androgenetic Diploid, pada PHM adalah Triploid, sedangkan $\boldsymbol{R} \boldsymbol{M}$ adalah Biparetal inherited Complete Hydatidiform Mole (BiCHM).

Selama ini, kita menangani $\boldsymbol{G T N}$ atau Penyakit Trofoblas Gestasonal(PTG) melalui paradigma Clinical Medicine, tetapi tidak selamanya berhasil. Sedangkan kita sudah tahu bahwa ada keanekaragaman klinik pada Penyakit Trofoblas. ${ }^{21}$ Di bawah ini kita sampaikan dua contoh kasus.

\section{Kasus I}

Seorang wanita, 24 tahun, P0A1, dikuret pada bulan April 2004, atas indikasi perdarahan.

$\begin{array}{ll}\text { Hasil PA-nya } & \text { : Mola Parsialis. Kadar } \beta \text { hCG } 5035 \mathrm{mlIU} / \mathrm{ml} . \\ \text { Status Presens } & \text { : Dalam Batas Normal } \\ \text { Status Ginekologi } & \text { : Uterus sedikit membesar. } \\ \text { USG } & : \text { Mola Invasif dengan Kista Lutein. } \\ \text { D/ } & : \text { Mola Invasif dengan Skor Prognostik } 3 . \\ \text { Th/ } & : \text { Etoposid } 100 \mathrm{mg} / \text { per hari, lima hari berturut-turut, dengan jarak } \\ & \text { Paktu satu minggu, antara dua pengobatan. } \\ \text { Prognostik } & \text { Setelah empat kali pengobatan : Complete Remission }\end{array}$

\section{Kasus II}

Seorang wanita 30 tahun, P0A1, telah dikuret dua kali pada bulan Juni 2001, atas indikasi persangkaan Mola Hidatidosa. Pemeriksaan PA, tidak dilakukan. Kadar $\beta$ hCG 99.605 mIU/ml.

USG

Foto thoraks

$\mathrm{D} /$

$\mathrm{Th} /$

Prognosis
: Koriokarsinoma dengan kemungkinan perforasi uterus.

: Metastasis : (-).

: Koriokarsinoma Stad I dengan Skor Prognostik 4.

: Epitosid $100 \mathrm{mg} /$ per hari, lima hari berturut-turut, dengan jarak satu minggu, antara dua pengobatan.

: Complete Remission baru dicapai setelah tiga bulan diberikan delapan kali pengobatan. 
Tiga tahun kemudian, si ibu, kembali hamil, dengan hasil anak yang matur, normal dan sehat.

Kalau dilihat dari segi umur, paritas, Skor Prognostik dan cara terapi, kedua kasus tersebut dapat dianggap sebanding, tetapi hasilnya berlainan. MENGAPA?

- $\quad$ Mengapa pada kasus II, diperlukan Etoposid yang lebih banyak?

- $\quad$ Apakah ada perbedaan genetik antara keduanya?

- $\quad$ Apakah kalau digunakan Personalized Medicine, akan berhasil?

Selama ini, di RS Dr. Hasan Sadikin, sepengetahuan penulis, Personalized Medicine belum pernah digunakan untuk mengobati penyakit trofoblas, terutama jenis yang ganas.

Dari semua informasi tentang Personalized Medicine itu, baik yang berskala internasional maupun nasional, para pakar kesehatan, pada umumunya setuju tentang kehadiran paradigma baru ini dalam dunia kedokteran/kesehatan, terutama dalam pengertian falsafah, normatif konseptual. Mereka juga sependapat, konsep dasar dan aplikasi kliniknya, terdapat kendala yang cukup besar, termasuk di dalamnya kendala teknis, politis(kebijakan) dan organisatoris keuangan.

Karena itu, dengan hadirnya Personalized Medicine, tidak berarti paradigma lainnya, seperti Clinical Medicine, EBM dan Genome Medicine, akan hilang. Semua tetap ada, tetapi penggunaannya masing-masing, bergantung kepada keadaan. Contohnya, dokter yang bertugas di kota besar, di mana sarana dan prasarana ilmu/bioteknologi semua tersedia, keempat paradigma itu dapat digunakan dan dikembangkan. Tetapi untuk mereka yang bertugas di daerah terpencil, bukti keprofesionalannya hanya bisa diwujudkan melalui Clinical Medicine saja.

\section{Daftar Pustaka}

1. William Osler. Dikutip dari Jonsen AR et al. Clinical Ethics, $5^{\text {th }}$ ed. Mac Graw HillComp, 2002.

2. Martaadisoebrata D. Perkembangan Obstetri Ginekologi Sosial. Bunga Rampai Obsteri Ginekologi Sosial. YBPSCP, 2005.

3. Sass HMartin. Bioethics: Its Philosophical basis and Application: Bioethics, Issues and Perspectives, 1990, Pan American Health Organization, Washington, USA.

4. Archie Cochrane : Effectifness and Efficiency: Random Reflection on Health Service(1972).

5. David Sackett, Rosenberg WMC, Muir Gray JA et al. Evidence Based Medicine : what is and what isn't. BJM 1996; 71.

6. Jenicek M. Epidemiology, evidencebased medicine, and evidence-based public health. J Epidemiol, 1997 Dec;79(4): 187-97.

7. Dhavendra Kumar. From evidence-based medicine to genomic medicine. Genomic Med. 2007 September: 1(3-4): 95-104.

8. Raykumar T. Personalized Medicine: FACs. Indian J Pediatr Onco. 2010 AprJun; 31(2): 7-74.

9. Jonsen AR, Siegler M and Windslade WJ. Clinical Bioethics, $5^{\text {th }}$ ed. MacGraw-Hill Comp, 2002.

10. Miles A, Loughlin $M$ and Polychroni A. Evidence-based healthcare, clinical knowledge and the rise of personalized medicine. $\mathrm{J}$ Evaluation in Clinical Practice, Vol 14; 5: 621-649, Oct 2008.

11. Miles A, Juan Mezzich. htpp://www. ijpcm.org/index.php/IJCM/article/ view/61

12. International Conference on Personalized Medicine, Silicon Valley, 26 Januari 2015.

13. $3^{\text {th }}$ International Conference on Predictive and Preventive Personalized Medicine and Moleculer Diagnostics, Valencia, Spain, 1-3 September 2015.

14. Mark Kris . Personalized Medicine. http:/ 
www.mskcc.org/cancer-care/adult/lungnon-small-cell/personalized medicine

15. Rhedi Meisudi. Personalized Medicine di badang Onkologi di Indonesia. Kalbe genomics Laboratory, Jakarta, Indonesia.

16. http://www.personalized medicine.com

17. Wikipedia. Personalized Medicine.http// en.wikipedia.org/wiki/Personalized Medicine

18. Harian Konpas (18 Juni 2009). Personalized Medicine sebagai Personalisasi Perawatan.

19. Hera Noviana Dr. Kalbe Genomic Laboratory (19 Mei 2011).

20. David H Mulyono Prof. Integrasi Ilmu Dasar - Ilmu Klinik. Harian Kompas 2012.

21. Martaadisoebrata D. Keanekaragaman Klinik Penyakit Trofoblas Gestasional. CV Sagung Seto 2011. Jakarta. 